\title{
Recent carbonatitic magmatism in Angola: the dykes of the Chiva lagoon maar
}

\author{
Marc Campeny, Joan C. Melgarejo, José Mangas, José Manuel, Antonio O. Gonçalves
}

\begin{abstract}
Marc Gampeny
mcampenycr@gmail.com

Museu de Ciències Naturals de Barcelona (Departament de Mineralogia). Passeig Picasso s/n 08003 - Barcelona, Catalonia.

Departament de Mineralogia, Petrologia i Geologia Aplicada, Universitat de Barcelona. c/Martí i Franquès s/n 08028 - Barcelona, Catalonia.
\end{abstract}

\section{Joan C. Melgarejo}

Departament de Mineralogia, Petrologia

Geologia Aplicada, Universitat de Barcelona. c/Martí i Franquès s/n 08028 - Barcelona, Catalonia.

\section{José Mangas}

Departamento de Física, Instituto de Oceanografía y Cambio Global, Universidad de Las Palmas de Gran Canaria, Campus universitario de Tafira 35017 - Las Palmas de Gran Canaria, Spain.

\section{José Manuel}

Antonio O. Gonçalves

Departamento de Geologia, Universidade Agostinho Neto, Avenida 4 Febreiro, 71 , CP815 - Luanda (Angola).

BOL. SOC. GEOL. MEX. 2017

VOL. 69 NO. 1

P. $209-222$

\section{ABSTRACT}

Chiva is a circular lagoon with a diameter of $900 \mathrm{~m}$, located in the vicinity of the Catanda graben (Angola). This area is largely covered by Quaternary lacustrine sediments, however, a few dykes of carbonatitic composition have been found near the SE shore of the lagoon. The intrusion of these carbonatitic dykes has been linked to the occurrence of recent volcanic events in the Chiva area and interpreted as feeding channels of an eruptive centre with maar morphology. The Chiva carbonatitic dykes show a finely porphyritic texture formed by phenocrysts of subhedral calcite $(60 \%)$, apatite $(30 \%)$ and magnetite $(10 \%)$ hosted in a fine calcite-rich ground mass that also contains accessory minerals such as pyrochlore, perovskite and kimzeyite. The mineralogical and compositional features of the Chiva dykes are similar to those described in some of the carbonatitic lavas from the Catanda graben, suggesting that both volcanic events are genetically related. The finding of this new eruptive centre enlarges the carbonatitic domain of Catanda and opens the door to the discovery of new carbonatitic outcrops in this region of Western Angola.

Keywords: carbonatites, carbonatitic dykes, maar, Angola, Catanda, Chiva

\section{RESUMEN}

En las inmediaciones del graben de Catanda (Angola) se localiza una laguna circular de 900 metros de diámetro conocida como laguna de Chiva. Aunque éste área se encuentra mayoritariamente cubierta por sedimentos lacustres, hay afloramientos de un pequeño grupo de diques de composición carbonatítica en la orilla SE de la laguna. La intrusión de estos diques carbonatíticos se relaciona con el desarrollo de eventos volcánicos en la zona de Chiva y se interpreta como los antiguos canales de alimentación de un centro eruptivo que desarrolló una morfología de maar. Los diques carbonatíticos de Chiva presentan una típica textura porfidica formada por fenocristales subhedrales de calcita (60\%), apatito (30\%) y magnetita (10\%) implantados en una matriz de calcita de grano fino con cantidades accesorias de pirocloro, perovskita y kimzeyita. Las características mineralógicas y composicionales de los diques del maar de Chiva son equivalentes a las descritas en las lavas carbonatíticas del graben de Catanda, lo que sugiere que ambos procesos volcánicos están relacionados genéticamente. El hallazgo de este nuevo centro eruptivo amplía la zona de desarrollo del vulcanismo carbonatítico en Catanda y abre la puerta al posible descubrimiento de nuevos afloramientos carbonatíticos extrusivos en esta zona occidental de Angola.

Palabras clave: carbonatitas, diques carbonatíticos, maar, Angola, Catanda, Chiva. 


\section{Introduction}

Carbonatites are igneous rocks composed of more than $50 \%$ of carbonates and less than $20 \mathrm{wt} \%$ of $\mathrm{SiO}_{2}$ (Le Maitre, 2002). However, their classification is still under discussion and many authors consider that magmatic rocks should be classified as carbonatites when they contain more than 30 $\%$ of modal carbonates, not including the $\mathrm{SiO}_{2}$ content (Mitchell, 2005). Carbonatites can be plutonic, hypabyssal or volcanic depending on their emplacement. They are typically associated to rift structures that are developed inside continental cratons (Le Bas, 1986), although they can be also related to other geological settings such as oceanic islands (Mangas et al., 1996; Widom et al., 1999) or orogenic belts (Tilton et al., 1998; Chakhmouradian et al., 2008).

According to experimental petrology data and isotopic studies of stable and radiogenic isotopes, is considered that carbonatitic magmas are originated in the lithospheric mantle (Wallace et al., 1988; Bell and Simonetti, 2010). Carbonatitic melts are marked by their high content in volatile elements, especially $\mathrm{CO}_{2}$ but also $\mathrm{F}$, and their enrichment in strategic elements such as Rare Earth Elements, $\mathrm{Nb}$ or Ta (Wyllie et al., 1996; Chakhmouradian, 2006; Chakhmouradian and Wall, 2012). This point has generated a great interest in the study of carbonatites despite their rarity since only 527 carbonatite localities have been reported in the world. An important part of the research studies in carbonatites are focused on the study of extrusive localities, since volcanic products can provide very significant information about the genesis and the composition of carbonatitic magmas and the understanding of experimental petrology data.

Extrusive carbonatites are extremely rare rocks, only 47 localities have been reported in the world until present-day (Woolley and Church, 2005; Woolley and Kjarsgaard, 2008). The majority of extrusive carbonatites are located in Africa and especially in the Eastern Rift where the only occurrence of an active carbonatitic volcano is found, the Ol Doinyo Lengai in Tanzania (Daw- son, 1962; Dawson et al., 1995; Keller and Zaitsev, 2012). In the western margin of the African continent a magnificent example of carbonatitic volcanism is also reported: the volcanic area of Catanda (Kwanza Sul, Angola). It is formed by a group of small monogenetic volcanic buildings of carbonatitic composition cropping out in a $50 \mathrm{~km}^{2}$ graben hosted in Archean granites and it is delimited by the intersection of three different fault systems. The Catanda carbonatitic volcanoes are largely eroded and covered by Quaternary colluvial and epiclastic sediments, which partly obscure the original morphology of the volcanic edifices. However, seven different eruptive centres were distinguished, associated to tuff ring and maar morphologies (Figure 1; Campeny et al., 2014).

The emplacement of the Catanda volcanic carbonatites is associated to the extensional domain of the Lucapa belt, which is a rift corridor defined by the NE-SW trending fractures of the Quilengues-Andulo fault system (Jelsma et al., 2009). The first magmatic activity reported in the Lucapa corridor is from the Paleoproterozoic (Sykes et al., 1978) but magmatism was also significantly important in the Upper Cretaceous, associated to the break-up of Gondwana and the corresponding opening of the South Atlantic Ocean (Moulin et al., 2010). Most of the Angolan carbonatites and kimberlites are distributed along Lucapa (Alberti et al., 1999) and were emplaced during the Cretaceous magmatic event (Torró et al., 2012; Calvo et al., $2011 \mathrm{a}$; Calvo et al., 2011b; Robles-Cruz et al., 2012). Silva and Pereira (1973) and Torquato and Amaral (1974) reported a Cretaceous age for the Catanda carbonatitic volcanism of $92 \pm 7$ Ma based on the K/Ardating of phlogopite from a tinguaite dyke outcropping in the area. However, the well-preserved morphology of the volcanic edifices, the nature of the pyroclastic materials and the existence of present-day geothermal and seismic activity in the same area suggest a recent age for these eruptive processes (Campeny et al., 2014; Campeny, 2016).

During the study of satellite images of the Catanda volcanic area we localised a small circular 


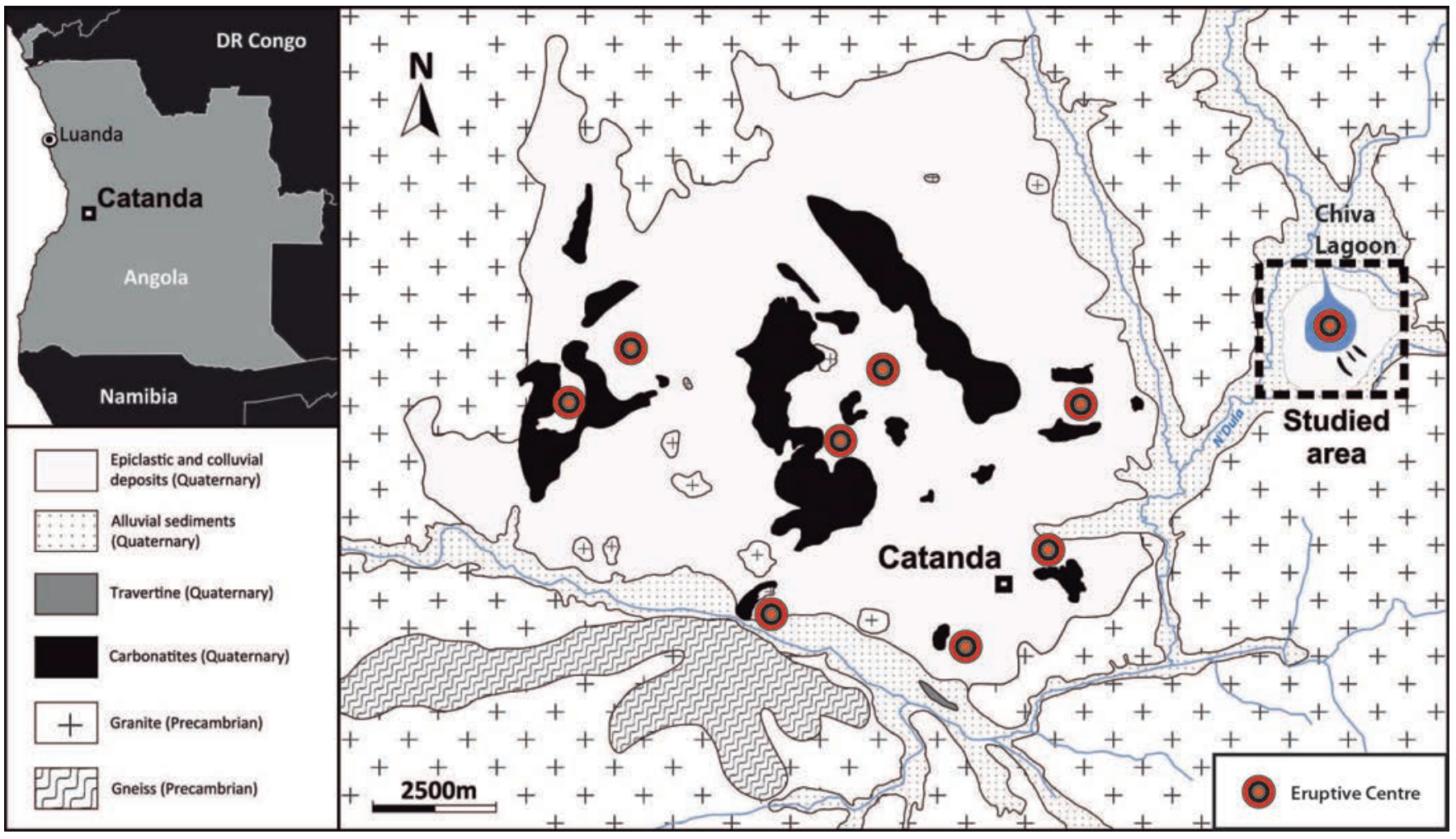

Figure 1 Geological map of the Catanda graben and the area of the Chiva lagoon (modified after Campeny et al.,2014).

lagoon in the Chiva area, located outside of the Catanda graben and slightly far away from the main carbonatite outcrops. Field work carried out in the surroundings of this lagoon allowed us to distinguish carbonatitic dykes, thus indicating the possible relation of this area with the occurrence of the carbonatitic volcanism in Catanda (Campeny et al., 2014; Campeny et al., 2015). The aim of this work is to provide new information about the nature of the materials of the Chiva lagoon and to discern whether their formation is related to the carbonatitic volcanism of the Catanda region or whether it should be considered as a genetically independent event.

\section{Methods}

The petrographic study of carbonatitic rocks from the Chiva area was based on the identification of main rock-forming minerals and the description of textural features. It has been carried out by the use of optical microscopy using transmitted and reflected light. Scanning Electron Microscopy E-SEM was also used for more detailed analyses of mineralogical relationships and textures, using a Quanta 200 FEI XTE 325/D8395BSE with a Genesis EDS microanalysis system from the Scientific and Technical Centres of the University of Barcelona (CCiTUB). The operating conditions of the SEM were $20-25 \mathrm{keV}, 1 \mathrm{nA}$ beam current and a working distance of $10 \mathrm{~mm}$ from the sample to the detector. Detail images of the textural patterns were obtained in back-scattered electron (BSE) mode.

Geochemical data of major and trace element compositions were obtained by performing X-ray fluorescence (XRF) (Norrish and Hutton, 1969) and ICP-emission spectrometry following a lithium metaborate/tetraborate fusion, respectively, at the ACTLABS Activation Laboratories Ltd. in Ancaster, Canada. 


\section{The Chiva Carbonatites}

The Chiva lagoon, which is considered to be the source of the N'Dula river, islocated $350 \mathrm{~km} \mathrm{SE}$ of Luanda and $5 \mathrm{Km}$ NE of the volcanic carbonatitic outcrops of Catanda (Figure 1). It forms a shallow depression of 900 metres in diameter, surrounded by a smooth relief that defines a typical ring shape (Figure 2a). In the vicinity of the lagoon, farming activity is developed and original outcrops are largely covered by alluvial and colluvial sediments. However, a few carbonatitic dykescan be distinguished on the SE edge of the lagoon, forming coherent 1.5-metre-thick bodies (Figure 2b), radially arranged from the lagoon centre to its border. Outcrops are brownish in colour when weathered and dark grey in fresh sample (Figure2c).

\subsection{PETROGRAPHY}

Carbonatitic dykes from the Chiva lagoon have a porphyritic texture with $20-25 \%$ of phenocrysts and xenocrysts in a carbonate-rich aphanitic groundmass (Figure 3a), which also contains a large number of vesicles.

\subsubsection{PHENOCRYSTS}

The population of phenocrystsis made up of calcite, apatite and magnetite. Calcite represents around $60 \%$ of modal phenocrysts of the Chiva dykes, such as reported in the Ipunda lavas from Catanda area (Table 1). Calcite crystals are subhedral, with a distinct tabular habit and attain up to $0.25 \mathrm{~mm}$ in length (Figure 3a). However, they have an internal polycrystalline texture, suggesting recrystallization and pseudomorphosis processes (Figure 3b). Apatite crystals are subhedral to euhedral, composed by prisms and hexagonal bipyramids; they are short prismatic in habit and may reach a diameter of up to $0.3 \mathrm{~mm}$, representing 30 $\%$ modal of the total phenocryst population. They are slightly zoned, with rims enriched in britholite component; hence, the rims appear slightly brighter in SEM-BSE images than the cores of these crystals. Magnetite forms clearly zoned euhedral octahedral grains up to $0.4 \mathrm{~mm}$ in diameter
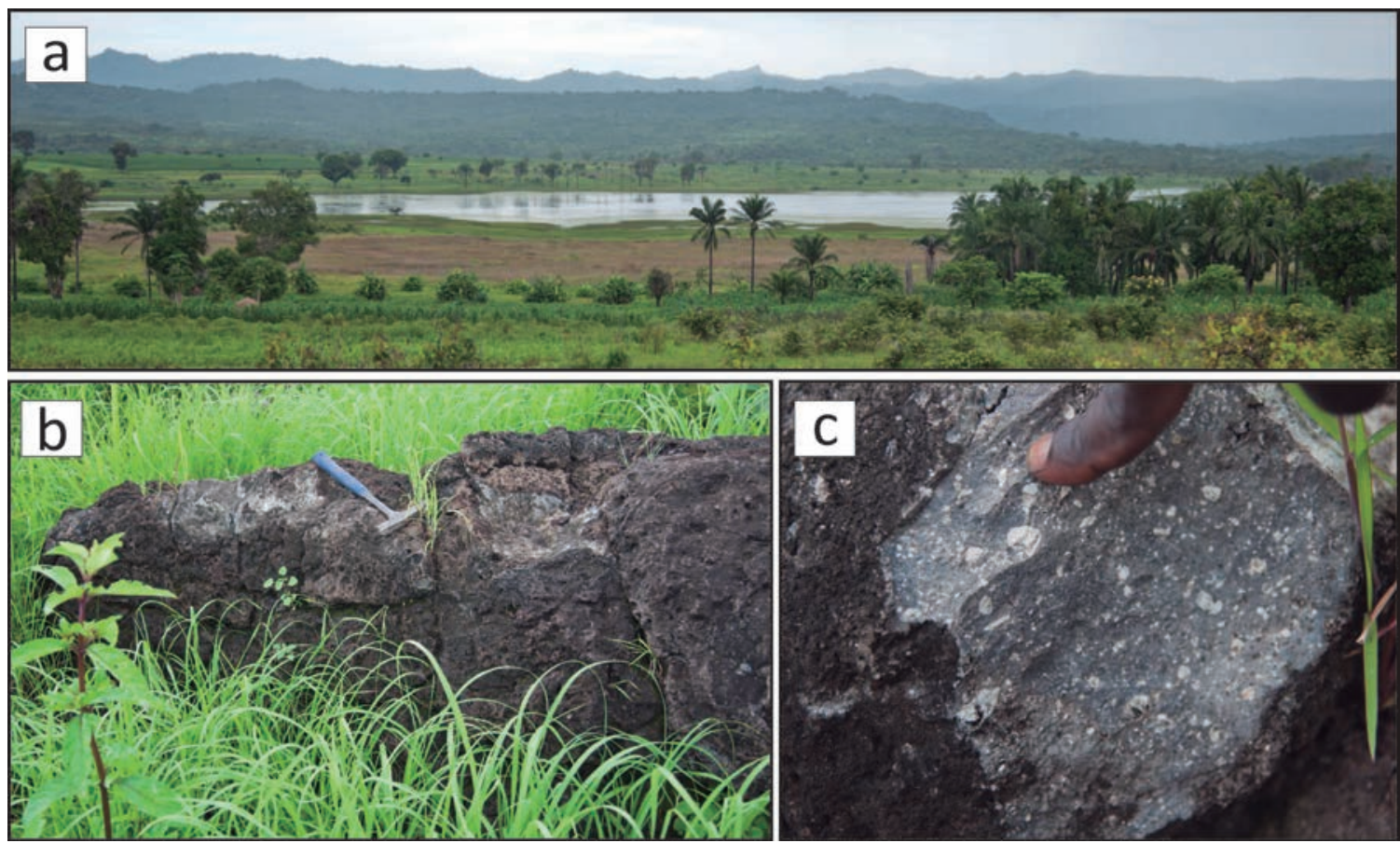

Figure 2 a. General view of the Chiva lagoon area. b. Carbonatitic dyke outcropping on the SE shore of the Chiva lagoon. c. Detail of typical porphyritic texture of the Chiva carbonatitic dykes. 

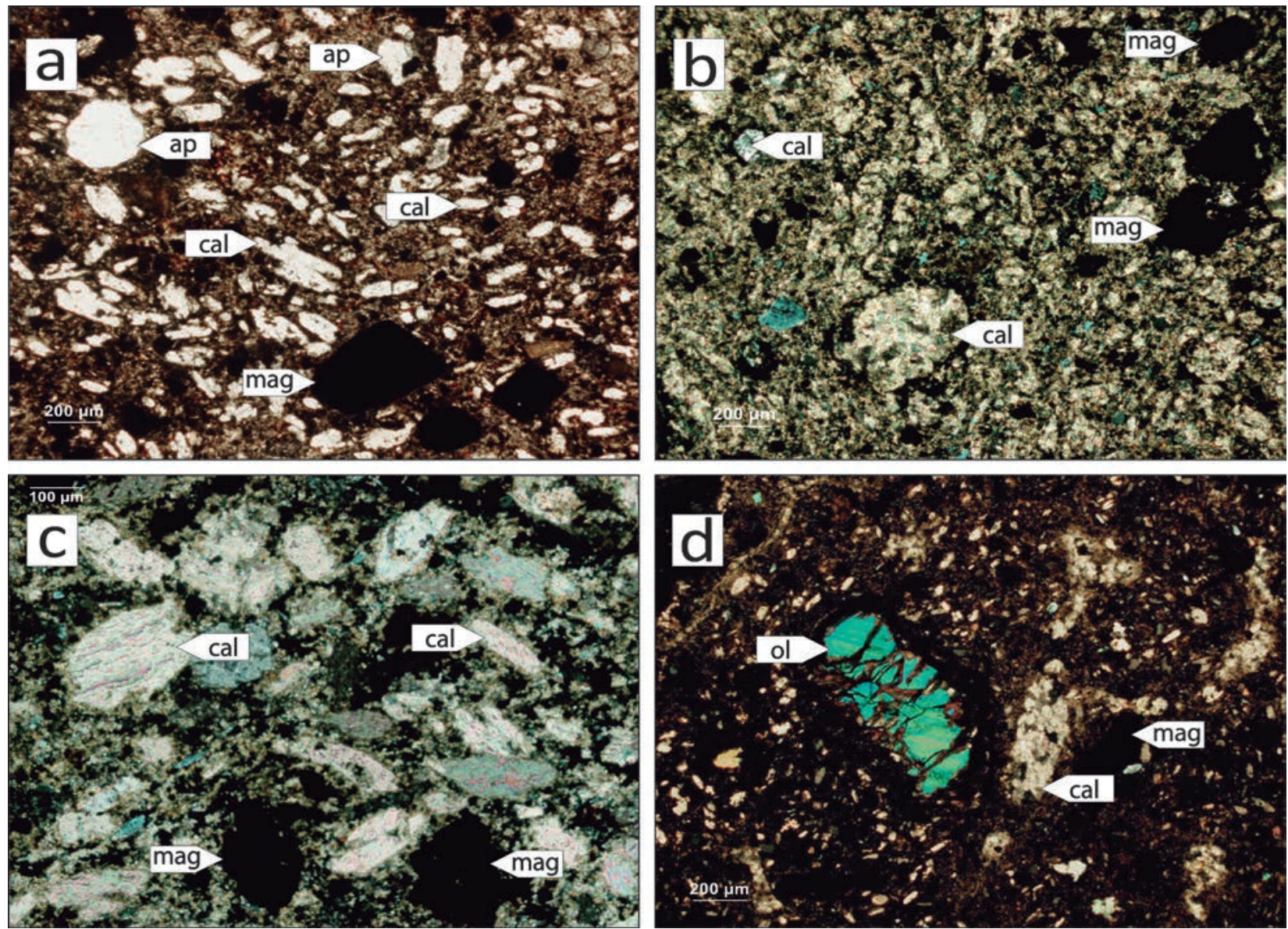

Figure 3 Plane-polarized light photomicrographs of Chiva carbonatitic dykes. a. General view (using parallel Nicols) of the carbonaterich groundmass mainly formed by calcite (cal) and magnetite (mag). b. Crossed Nicols picture of Apatite (ap), magnetite (mag) and calcite phenocrysts hosted in a carbonatite-rich groundmass. c. Subhedraltabular phenocrysts of calcite together with magnetite (mag). Picture taken using crossed Nicols. d. Pelletal lapilli core comprised of a partially fractured and altered olivine (ol) crystal. Picture taken using crossed Nicols.

representing around $10 \%$ modal (Figures 3a, 3b and $3 \mathrm{c}$ ).

\subsubsection{XENOCRYSTS}

Rounded and corroded olivine grains, up to 0.6 $\mathrm{mm}$, partly or completely replaced by serpentine minerals are common and may be interpreted as xenocrysts (Table 1; Figure 3d). In fact, olivine from the Catanda carbonatites has generally been interpreted as xenocrysts by different authors (Peres et al., 1968; Campeny et al., 2015).

\subsubsection{GROUNDMASS}

The main components of the groundmass are calcite $(60 \%$ modal $)$, apatite $(10 \%$ modal $)$ and magnetite $(10 \%$ modal $)$, presenting textural patterns similar to those described in the phenocrysts (Table 1; Figure 4a). In addition, variable proportions of magnesium-rich smectites $(\approx 20 \%$ modal $)$ are widespread in the groundmass, forming cryptocrystalline masses that fill interstitial spaces (Figure 4). Minor proportions of accessory minerals such as pyrochlore and perovskite are also noticeable. The grain size of these minerals is very small, less than $5 \mu \mathrm{m}$ (Figures $4 \mathrm{a}$ and $4 \mathrm{~b}$ ), and they are scattered in the groundmass or can also appear as inclusions inside magnetite grains. Both minerals develop euhedral to subhedral crystals, and zoning is not evident. Pyrochloreis slightly enriched in $\mathrm{Zr}$ while $\mathrm{Nb}$ content in perovskite is below the detec- 
Table 1. Comparison of the mineral composition between Catanda graben lavas and carbonatitic dykes from the Chiva lagoon area.

\begin{tabular}{|c|c|c|c|c|}
\hline Location & Texture & Lithology & Composition & Mineralogy \\
\hline Huilala - Ungongué & Finely porphyritic & Lava & Aillikite & $\begin{array}{l}\text { * Microphenocrysts: fluorapatite (35\%), titaniferous magnetite ( } 35 \%) \text {, augite (15 } \\
\% \text { ), phlogopite }(15 \%) \\
\text { * Groundmass: calcite, fluorapatite, magnetite, pyrochlore, baddeleyite, cuspidine, } \\
\text { perovskite, periclase, brucite, zirconolite, spurrite, oldhamite } \\
\text { * Xenocrysts: olivine } \\
\text { * Xenoliths: glimmerite }\end{array}$ \\
\hline Jango & Finely porphyritic & Lava & Calciocarbonatite & $\begin{array}{l}\text { * Phenocrysts: fluorapatite }(60 \%) \text {, magnetite }(25 \%) \text {, phlogopite (10\%), augite (5\%) } \\
\text { * Groundmass: calcite, fluorapatite, magnetite, pyrochlore, baddeleyite, monticellite } \\
\text { * Xenocrysts: amphibole }\end{array}$ \\
\hline Utihohala & Finely porphyritic & Lava & Calciocarbonatite & $\begin{array}{l}\text { * Microphenocrysts: fluorapatite }(60 \%) \text {, magnetite }(20 \%) \text {, phlogopite }(15 \%) \text {, } \\
\text { augite }(5 \%) \\
\text { * Groundmass: calcite, fluorapatite, magnetite, pyrochlore, alabandite }\end{array}$ \\
\hline Ipunda & Trachytoid & Lava & $\begin{array}{l}\text { Altered } \\
\text { Natrocarbonatite }\end{array}$ & $\begin{array}{l}\text { * Microphenocrysts: calcite }(60 \%) \text {, fluorapatite }(15 \%) \text {, magnetite }(15 \%) \text {, } \\
\text { phlogopite }(5 \%) \text {, augite ( } 5 \%) \\
\text { * Groundmass: calcite, fluorapatite, magnetite, pyrochlore, baddeleyite } \\
\text { * Xenoliths: glimmerite }\end{array}$ \\
\hline Chiva lagoon & Finely porphyritic & Dyke & Calciocarbonatite & $\begin{array}{l}\text { * Microphenocrysts: calcite ( } 60 \%) \text {, fluorapatite }(30 \%) \text {, magnetite }(10 \%) \\
\text { * Groundmass: calcite, fluorapatite, magnetite, pyrochlore, perovskite, kimzeyite } \\
\text { * Xenocrysts: olivine }\end{array}$ \\
\hline
\end{tabular}

tion limit of the EDS. More rarely, we have also found small subhedral grains of kimzeyite garnet, up to $2 \mu \mathrm{m}$ in diameter.

\subsubsection{VESICULA INFILL}

Vesicular porosity is irregular in size and distribution. However, millimetre- to centimetre-sized amygdalae are rather common, and they are normally completely infilled by a supergene sequence of clay minerals, euhedral quartz and late spariticcalcite. Barite is also found in this assemblage as tiny crystals, less than $2 \mu \mathrm{m}$ in length, commonly included in the calcite groundmass.

\section{Geochemistry}

Major and trace element compositions of Chiva carbonatitic dykes are compiled in Table 2. It also includes compositional values from different worldwide carbonatite localities for comparison, such as the lavas from the Catanda area (Angola), Fort Portal (Uganda), Oldoinyo Lengai volcano (Tanzania) and the aillikites from Aillik Bay (Canada) (Tappe et al., 2006; Eby et al., 2009; Keller and Zaitsev, 2012; Campeny et al., 2015).

The carbonatitic dykes of the Chiva area have
$\mathrm{CaO}$ contents of 35.52 to $34.27 \mathrm{wt} \%$. These values are similar to those reported in the aillikitic and calcio carbonatitic lavas from the Catanda area and the carbonatitic lavas from Fort Portal, but significantly higher in comparison to the aillikites from Aillik Bay and the Oldoinyo Lengai fresh natrocarbonatite lavas. Despite that, altered natrocarbonatic lavas from Catanda and the Oldoinyo Lengai area present higher values of $\mathrm{CaO}$, varying from 45.91 to $46.81 \mathrm{wt}^{\%} \%$ (Table 2). In the case of $\mathrm{MgO}$, Chiva dykes show values from 9.13 to 9.80 $\mathrm{wt} \%$, similar to the aillikitic and calciocarbonatitic lavas from Catanda and Fort Portal (Table 2). $\mathrm{FeO}_{\mathrm{t}}$ contents range from 8.40 to 8.34 and are also similar from those which are presented by the aillikitic and calciocarbonatitic lavas from Catanda, butthey are significantly lower than those reported in the Fort Portal lavas and, especially, in comparison to aillikites from Aillik Bay, that present values from 12.2 to $16.0 \mathrm{wt}^{\%} \% \mathrm{FeO}_{\mathrm{t}}$ (Table 2).

$\mathrm{SiO}_{2}$ totals vary between 12.7 and $13.5 \mathrm{wt}^{\%} \%$ in Chiva dykes (Table 2), with similar contents to those reported in the calciocarbonatite lavas from the Catanda area, as well as in the lavas from Fort Portal (Table 2). In the case of the aillikitic rocks from Catanda and Aillik Bay, $\mathrm{SiO}_{2}$ values are significantly higher than in Chiva, varying from 

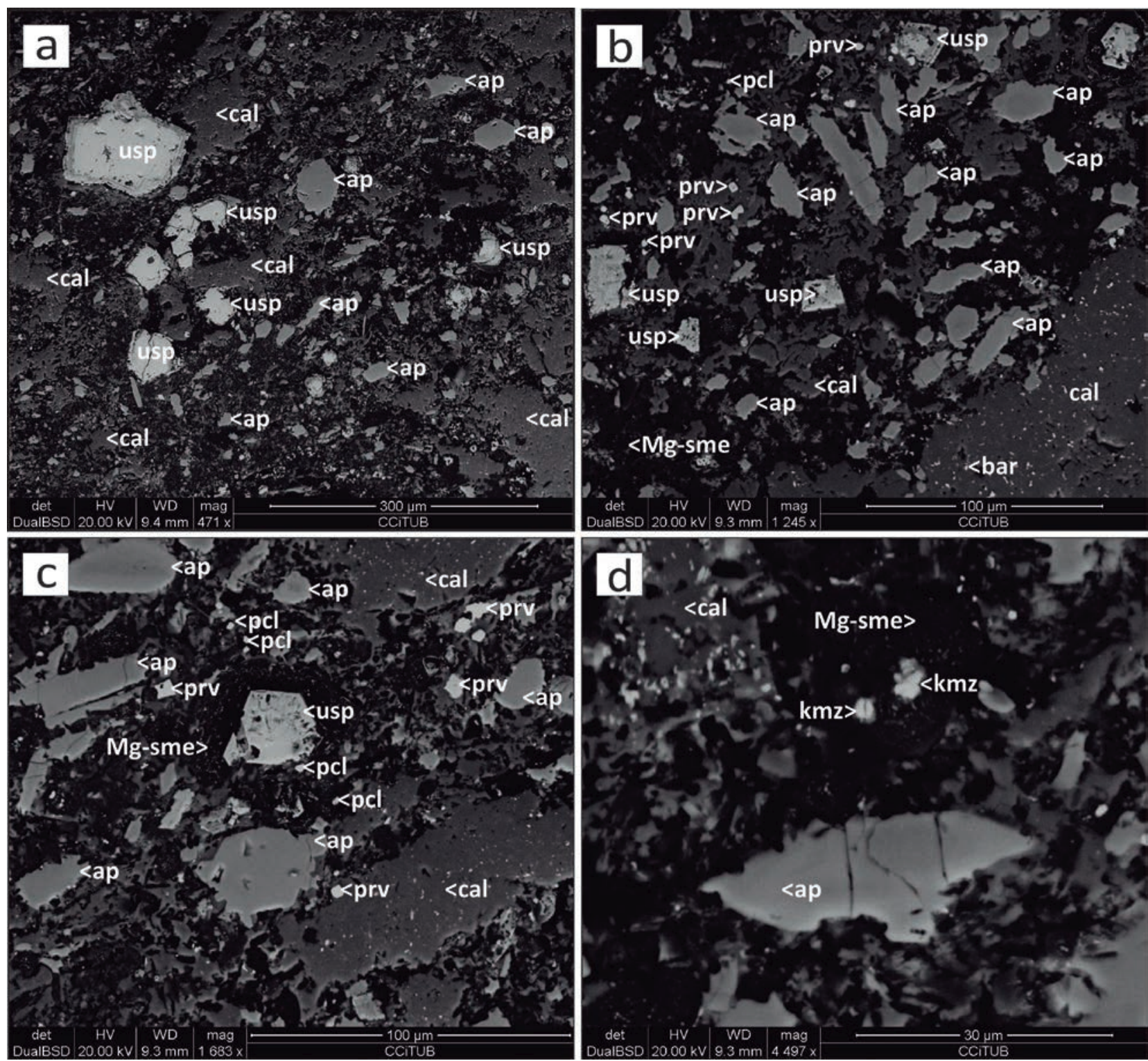

Figure 4 Backscattered scanning electron microscope (SEM) images of Chiva carbonatitic dyke samples. a. General view of typical porphyritic texture with magnetite (mgt), calcite (cal) and apatite (ap) microphenocrysts. b. Apatite (ap) prismatic crystals along side small grains of perovskite (prv) and magnetite ( $\mathrm{mgt}$ ), present in a calcite-rich (cal) groundmass, with abundant small inclusions of barite (bar) and magnesium-rich smectite (Mg-sme) in interstitial spaces. c. Detail of the groundmass with pyrochlore (pcl), perovskite (prv) and microphenocrysts of apatite (ap), magnetite (mgt) and calcite (cal) and interstitial magnesium-rich smectite (Mg-sme). d. Subhedral grains of kimzeyite $(\mathrm{kmz})$ hosted in magnesium-rich smectite (Mg-sme) and associated to a calcite groundmass (cal) and a subhedral prismatic grain of apatite (ap).

14.29 to 23.33 and from 18.2 to 26.8 , respectively. We also carried out a general comparison between $\mathrm{SiO}_{2}$ contents and the proportion of different elements found in Chiva dykes, that also include data from different carbonatitic rocks worldwide (Figure 5). In these diagrams it is possible to distinguish that the main compositional features of
Chiva dykes are especially similar to those reported in the calciocarbonatitic lavas of the Catanda area (Figure 5).

Chiva dykes have a significant enrichment in REE, presenting LREE contents from 100 to 1000 times higher to those reported in $\mathrm{Cl}$ chondrites and 10 to 100 times enriched in the case of HREE (Figure 


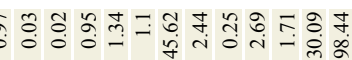

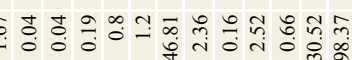

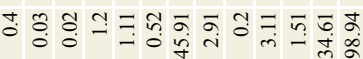

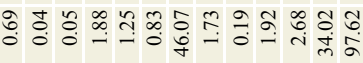

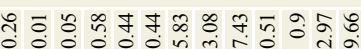

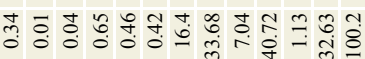

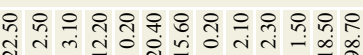

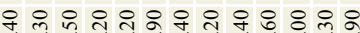
i่m

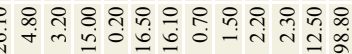

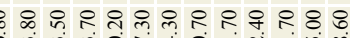

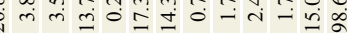

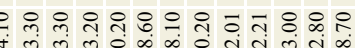
0000000000

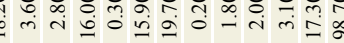

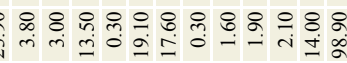

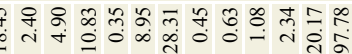

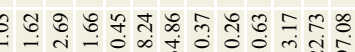

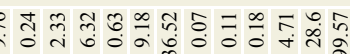

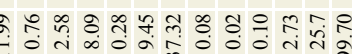

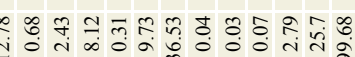

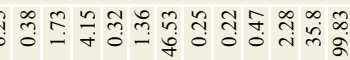

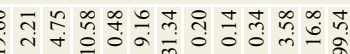

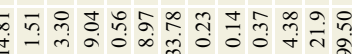

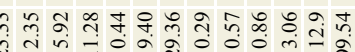

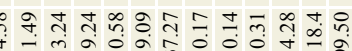

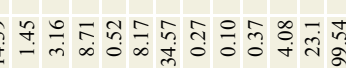

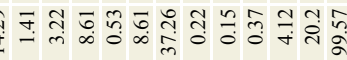

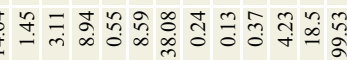

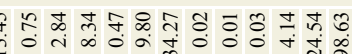

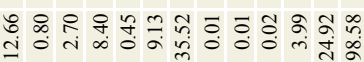

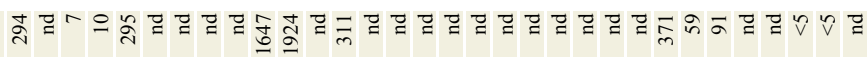

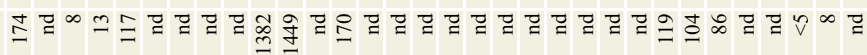

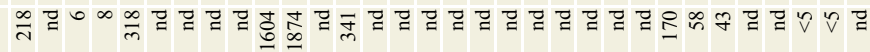

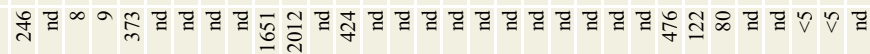

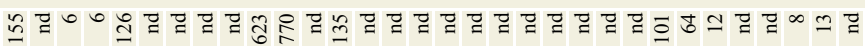

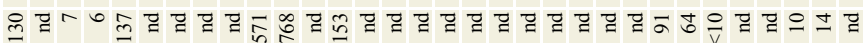

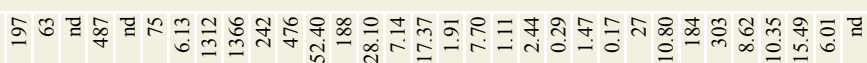

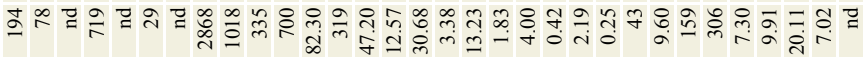

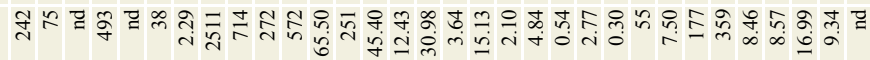

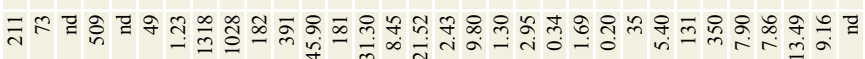

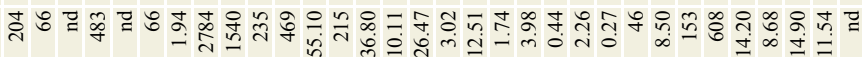

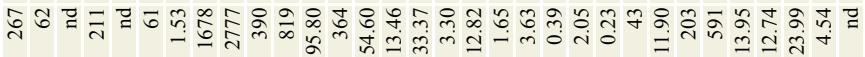

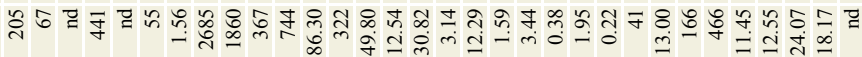

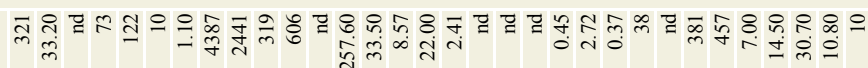

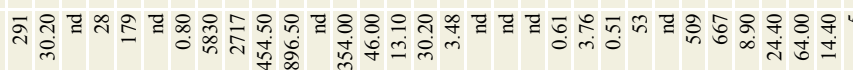

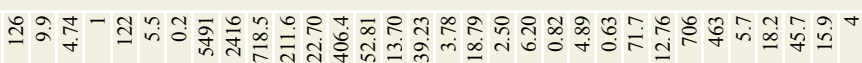

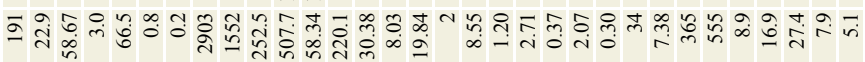

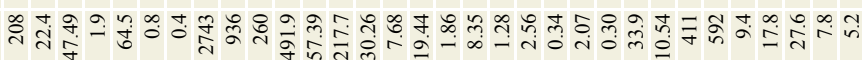

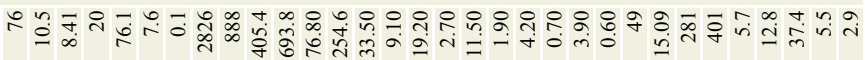

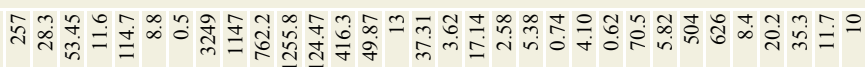

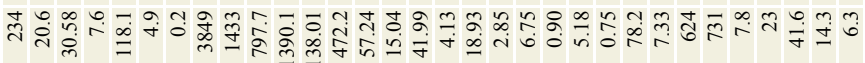

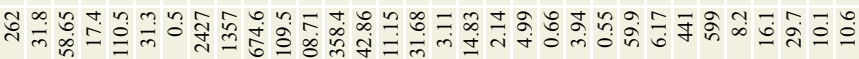

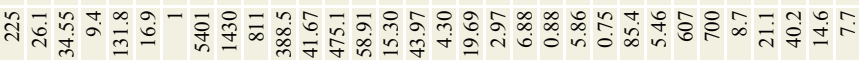

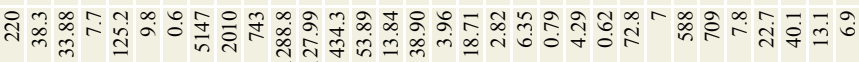

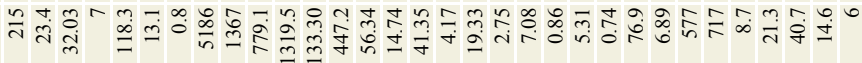

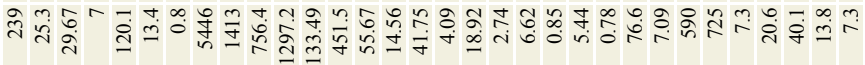

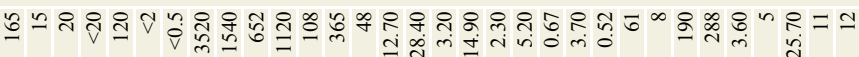

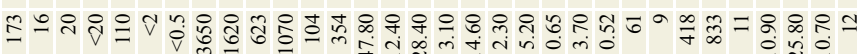



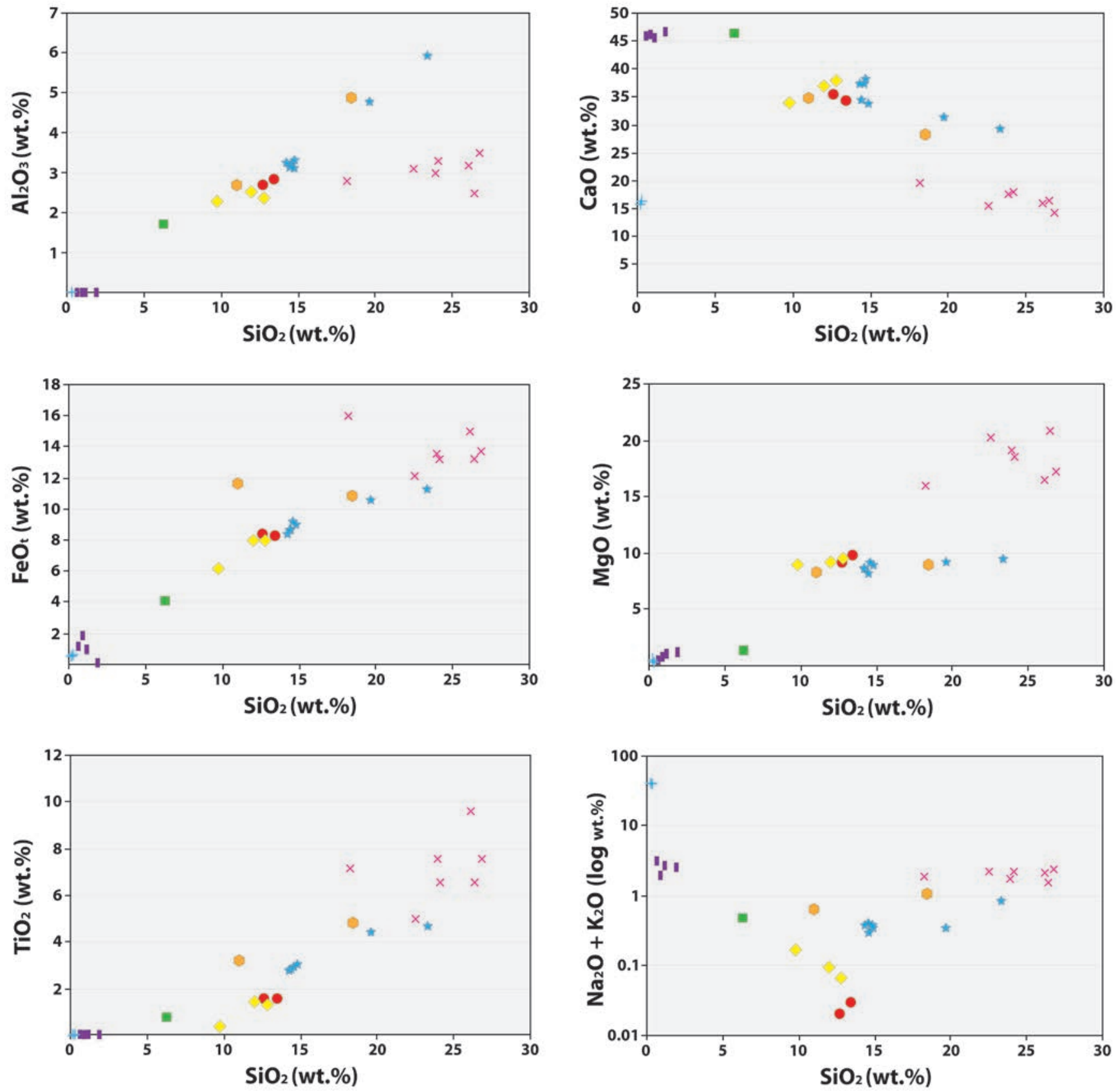

- Carbonatitic dykes (Chiva lagoon)

- Altered natrocarbonatite lavas (Catanda)

- Calciocarbonatite lavas (Catanda)

* Aillikite lavas (Catanda)
+ Fresh natrocarbonatite lavas (Oldoinyo Lengai)
- Altered natrocarbonatite lavas (Oldoinyo Lengai)
- Carbonatite lavas (Fort Portal)
$\times$ Aillikite rocks (Aillik Bay) 
6a). General values are similar to those reported in other carbonatitic rocks (Table 2) but they are not significant enough to be evaluated as an economic resource. REE patterns of the studied carbonatitic dykes from Chiva show clear negative slopes with a significant enrichment in LREE relative to MREE and HREE. These are similar patterns to those presented by the Catanda graben lavas (Figure 6a).

Multi-element diagrams also show very similar patterns between Chiva dykes and Catanda graben lavas. The carbonatitic dykes are systematically enriched in all plotted elements (including LILE, HFSE and REE) to PM (Figure 6b).

\section{Discussion}

The dykes cropping out in the SE border of the Chiva lagoon indicate the development of carbonatitic magmatism events in this area. Furthermore, considering the proximity of Chiva to the Catanda graben, where volcanic carbonatitic activity is well known (Silva Pereira, 1973; Campeny et al., 2014; Campeny et al., 2015), both carbonatitic magmatic areas are probably related.

Mineralogical features of the Chiva carbonatitic dykes are very similar to those reported in the carbonatitic lavas from Catanda (Campeny et al.,
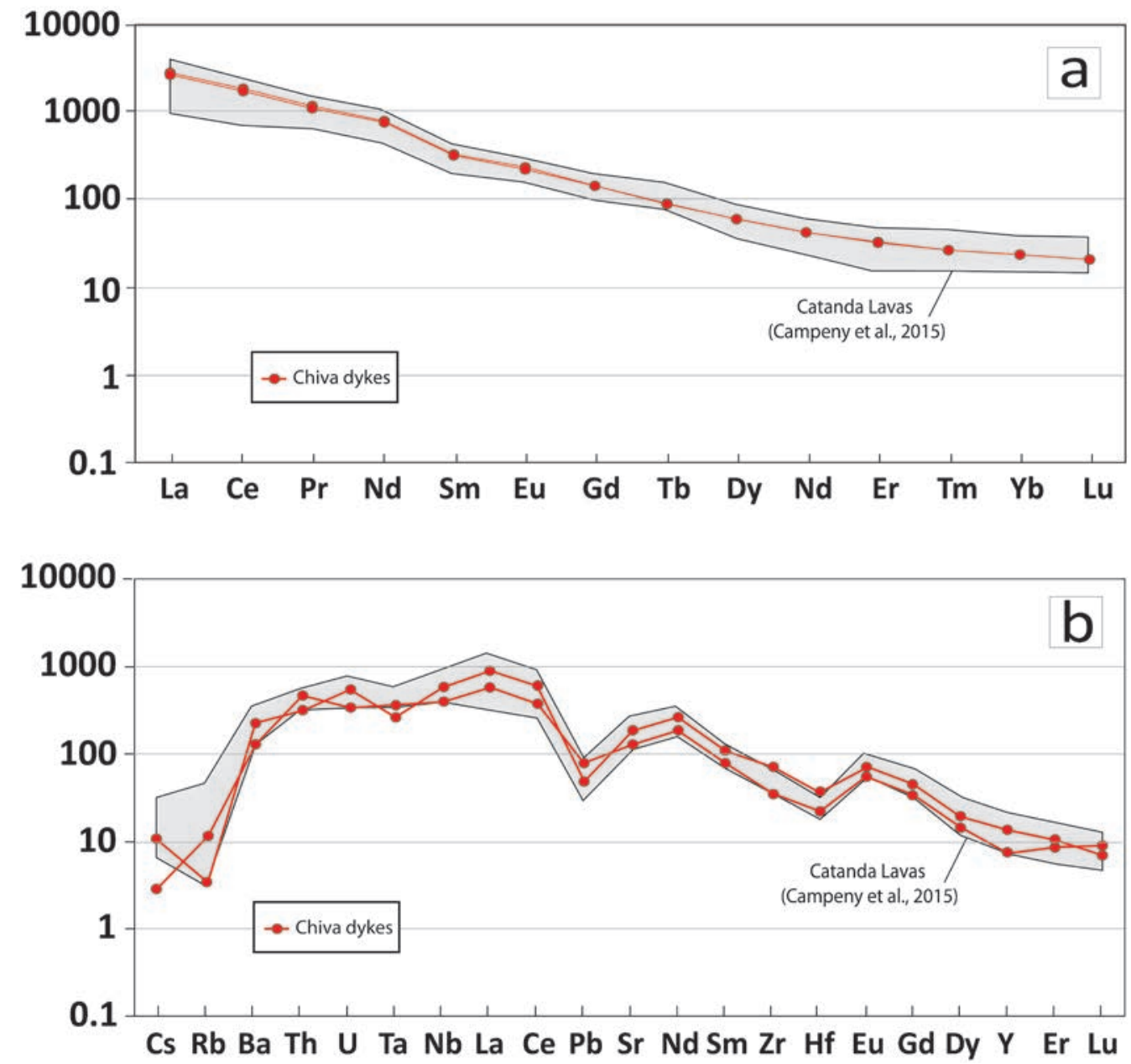

Figure 6 a. REE plot of Chiva carbonatitic dykes normalized to chondrite C1. b. Multi-elemental trace element composition of Chiva dykes normalized to primitive mantle (PM). Normalization values used in both diagrams are from Sun and McDonough (1989). Chiva carbonatitic dyke patterns are compared to Catanda lavas in both diagrams. Values from Campeny et al. (2015). 
2014; Campeny et al., 2015). Minerals such as calcite, apatite and magnetite are the main phenocryst phases in both localities, while the groundmass mineralogy is also equivalent. The latter is comprised of sparitic calcite and accessory minerals such as pyrochlore or perovskite; both reported in Chiva dykes and also in Catanda graben lavas (Table 1).

The comparison of major and trace element compositions between Chiva dykes and Catanda lavas also indicates a clear genetic relation. Multi-elemental and REE diagrams of Chiva carbonatitic dykes present equivalent patterns to those reported for Catanda lavas, suggesting that all these carbonatitic products were generated from the same parental melt. Major element composition is very heterogeneous in the case of Catanda lavas but the Chiva carbonatitic dykes are compositionally equivalent to the calciocarbonatitic lavas from Jango and Utihohala monogenetic cones. These volcanic edifices are also located in the most external part of the Catanda graben region (Campeny et al., 2014; Campeny et al., 2015). In addition, we can also conclude that carbonatitic dykes from Chiva present compositional and mineralogical features akin to other carbonatitic volcanic rocks worldwide such as Fort Portal (Uganda) (Eby et al., 2009).

Hence, considering the mineralogical and compositional features of the Chiva dykes, we conclude that these carbonatitic outcrops are related to the volcanic activity in Catanda despite the fact that Chiva is located outside of the Catanda graben. Therefore, we assume that carbonatitic volcanic activity in this area was also developed outside the limits of the Catanda graben and the discovery of new carbonatitic volcanic outcrops in this region should not be ruled out.

The radial distribution of the Chiva dykes, oriented from the lagoon centre to its border, and the morphology of the Chiva area, which is defined by a circular depressed ring, suggest that an eruptive centre was once located in the region. Hypabyssal intrusions related to volcanic edifices are common and broadly described in several volcanic areas of different composition worldwide (Gautneb and Guddmundsson, 1992; Geshi, 2005; Pasquarè and Tibaldi, 2007). Dykes are generated by magma intrusions during volcanic events and represent the magma path towards the surface (Corazzato et al., 2008).

Despite the fact that the morphology of the Chiva area is broadly eroded and covered by sediments and vegetation, the topographic position of the area, which is below the average altitude of surrounding terrains, suggests that the Chiva volcanic edifice has a maar morphology. Maars are volcanic constructions related to explosive activity and are commonly associated to recent carbonatitic volcanism such as in the Eifel region (Germany; Keller, 1981), San Venanzo (Italy; Stoppa, 1996), the East African Rift (Deans and Roberts, 1984; Woolley and Church, 2005) or even the volcanic edifices that stand out inside the Catanda graben (Campeny et al., 2014).

\section{Conclusions}

The main conclusions of our work can be summarized as follows.

- Dykes of carbonatitic composition outcrop in the SE border of the Chiva lagoon area (Angola). They have been interpreted as hypabyssal intrusive sheets related to the occurrence of recent volcanic activity, producing a single eruptive centre with typical maar morphology.

- Mineralogical and compositional features of the Chiva dykes are similar to those reported in the carbonatitic lavas of the Catanda graben area, suggesting that both volcanic events are genetically related. Moreover, the Chiva dykes also present compositional similarities to the volcanic silica-rich carbonatites of the Eastern African rift, such as Fort Portal (Uganda).

- The genetic relation between Chiva and the Catanda graben suggests that the recent carbonatitic volcanism of the Lucapa domain has a broader extension than previously sup- 
posed. The discovery of new carbonatitic volcanic localities outside the main Catanda graben should not be discarded in this region of Angola.

\section{Acknowledgements}

This research has been supported by projects 2014 SGR 1661 and SGR-444 of the Generalitat de Catalunya and research project CGL2009-13758 of the Spanish Government. Fieldwork has been funded by the Hugh E. McKinstry fund, granted by the Society of Economic Geologists (SEG) and the Departamento de Geologia of the Universidade Agostinho Netoin Luanda (Angola). We thank Eva Prats and David Artiaga of the Technical Centres of the University of Barcelona (CGiT) for their assistance during the SEM sessions. We especially acknowledge the collaboration and hospitality of the people of Catanda village.

\section{References}

Alberti, A., Castorina, F., Censi, P., CominChiaramoni, P., Gomes, C.B., 1999, Geochemical characteristics of Cretaceous carbonatites from Angola: Journal of African Earth Sciences, 29, 735-759.

Bell, K., Simonetti, A., 2010, Source of parental melts to carbonatites-critical isotopic constraints: Mineralogy and Petrology, 98, 77-89.

Calvo, A., Melgarejo, J.G., Bambi, A.C.J.M., Gonçalves, A.O., Alfonso, P., $2011 \mathrm{a}, \mathrm{Nb}$ and REE at the Bailundo carbonatite, Angola, in Barra, F. (ed.), Let's talk ore deposits: Antofagasta, Universidad Católica del Norte, 675-677.

Calvo, A., Melgarejo, J.C., Alfonso, P., Bambi, A.C.J.M., Gonçalves, A.O., $2011 \mathrm{~b}, \mathrm{Nb}$ and REE mobilization at the Longonjo carbonatite, Angola, in Barra, F. (ed.), Let's talk ore deposits: Antofagasta, Universidad
Católica del Norte, 681-683.

Campeny, M., 2016, Caracterización del vulcanismo carbonatítico de Catanda (Angola): Barcelona, University of Barcelona, PhD tesis, $151 \mathrm{p}$.

Campeny, M., Mangas, J., Melgarejo, J.C., Bambi, A., Alfonso, P., Manuel, J., 2014, The Catanda extrusive carbonatites (Kwanza Sul, Angola): an example of explosive carbonatitic volcanism: Bulletin of Volcanology, 76, 818-832.

Campeny, M., Kamenetsky, V.S., Melgarejo, J.C., Mangas, J., Manuel, J., Alfonso, P., Kamenetsky, M.B., Bambi, A., Gonçalves, A.O., 2015, Carbonatitic lavas in Catanda (Kwanza Sul, Angola): mineralogical and geochemical constraints on the parental melt: Lithos, 232, 1-11.

Chakhmouradian, A.R., 2006, High-field-strength elements in carbonatitic rocks: Geochemistry, crystal chemistry and significance for constraining the sources of carbonatites: Chemical Geology, 235, 138-160.

Chakhmouradian, A.R., Mumin, A.H., Demény, A., Elliott, B., 2008, Postorogenic carbonatites at Eden Lake, Trans-Hudson Orogen (northern Manitoba, Canada): geological setting, mineralogy and geochemistry: Lithos, 103, 503-526.

Chakhmouradian, A.R., Wall, F., 2012, Rare earth elements: minerals, mines, magnets (and more): Elements, 8 (5), 333-340.

Corazzato, C., Francalanci, L., Menna, M., Petrone, C.M., Renzulli, A., Tibaldi, A., Vezzoli, L., 2008, What controls sheet intrusion in volcanoes? Structure and petrology of the Stromboli sheet complex, Italy: Journal of Volcanology and Geothermal Research, 173, 26-54.

Dawson, J.B., 1962, Sodium carbonate lavas from Oldoinyo Lengai, Tanganyika: Nature, 195, 1075-1076.

Dawson, J.B., Pinkerton, H., Norton, G.E., Pyle, D.M., Browning, P., Jackson, D., Fallick, A.E., 1995, Petrology and geochemistry 
of Oldoinyo Lengai lavas extruded in November 1988: magma source, ascent and crystallization, in Bell, K., Keller, J. (eds.), Carbonatite Volcanism. Oldoinyo Lengai and the petrogenesis of natrocarbonatite IAVCEI Proceedings in Volcanology 4, 47-69.

Deans, T., Roberts, B., 1984, Carbonatite tuffs and lava clasts of theTinderet foothills, western Kenya: a study of calcified natrocarbonatites: Journal of the Geological Society of London 141, 563-580.

Eby, G.N., Lloyd, F.E., Woolley, A.R., 2009, Geochemistry and petrogenesis of the Fort Portal, Uganda, extrusive carbonatite: Lithos 113, 785-800.

Gautneb, H., Gudmundsson, A., 1992, Effect of local and regional on sheet emplacement in West Iceland: Journal of Volcanology and Geothermal Research, 51, 339-356.

Geshi, N., 2005, Structural development of dike swarms controlled by the change of magma supply rate: the cone sheets and parallel dike swarms of the Miocene Otoge igneous complex, Central Japan: Journal of Volcanology and Geothermal Research, 141, 267-281.

Jelsma, H., Barnett, W., Richards, S., Lister, G., 2009, Tectonic setting of kimberlites: Lithos, 112S, 155-165.

Keller, J., 1981, Carbonatitic volcanism in the Kaiserstühl alkaline complex: evidence for highly fluid carbonatitic melts at the Earth's surface: Journal of Volcanology and Geothermal Research, 9, 423-431.

Keller, J., Zaitsev, A., 2012, Geochemistry and petrogenetic significance of natrocarbonatites at Oldoinyo Lengai, Tanzania: Composition of lavas from 1988 to 2007: Lithos, 148, 45-53.

Le Bas, M.J., Rex, D.G., Stillman, G.J., 1986, The early magmatic chronology of Fuerteventura: Geological Magazine, 123, 287-298.

Le Maitre, R.W., 2002, Igneous Rocks: a Classification and Glossary of Terms.
Cambridge, Cambridge University Press, $236 \mathrm{p}$.

Mangas, J., Pérez Torrado, FJ., Martín Izard, A., Reguilón Bragado, R.M., 1996, Minerales de tierras raras en las carbonatitas del Complejo Basal de Fuerteventura (Islas Canarias): Geogaceta, 20 (7), 1511-1513.

Mitchell, R.H., 2005, Carbonatites and carbonatites and carbonatites: The Canadian Mineralogist, 43, 2049-2068.

Moulin, M., Aslanian, D., Unternehr, P., 2010, A new starting point for the South and Equatorial Atlantic Ocean: Earth-Science Reviews, 98, 1-37.

Norrish, K., Hutton, J.T., 1969, An accurate $\mathrm{X}$-ray spectrographic method for the analysis of a wide range of geological samples: Geochimica et Cosmochimica Acta 33, 431-453.

Pasquarè, F., Tibaldi, A., 2007, Structure of a sheet-laccolith system revealing the interplay between tectonic and magma stresses at Stardalur Volcano, Iceland: Journal of Volcanology and Geothermal Research, 161, 131-150.

Peres, A.M., Gomes, C.F., Cardoso-Simões, M.V., 1968, As variedades semi-preciosas de olivina da Catanda-Angola: Boletim dos Serviços de Geologia e Minas de Angola, 18, 5-15.

Robles-Cruz, S.E., Escayola, M., Jackson, S., Galí, S., Pervov, V., Watangua, M., Gonçalves, A., Melgarejo, J.C., 2012, U-Pb SHRIMP geochronology of zircon from the Catoca kimberlite, Angola: Implications for diamond exploration: Chemical Geology, 310-311, 137-147.

Silva, M.V.S., Pereira, E., 1973, Estrutura Vulcânico-Carbonatitica da Catanda (Angola): Boletim dos Serviços de Geologia e Minas de Angola, 24, 5-14.

Stoppa, F., 1996, The San Venanzo maar and tuff ring, Umbria, Italy: eruptive behaviour of a carbonate-melilitite volcano: Bulletin of Volcanology, 57, 563-577. 
Sun, S.S., McDonough, W.F., 1989, Chemical and isotopic systematics of oceanic basalts; implications for mantle composition and processes, in Saunders, A.D., Norry, M.J. (eds.), Magmatism in the ocean basins: London, Geological Society of London, 42, 313-345.

Sykes, L., 1978, Intraplate seismicity, reactivation of pre-existing zones of weakness, alkaline magmatism, and other tectonism postdating continental fragmentation: Reviews of Geophysics, 16, 621-688.

Tappe, S., Foley, S.F., Jenner, G.A., Heaman, L.M., Kjarsgaard, B.A., Romer, R.L., Stracke, A., Joyce, N., Hoefs, J., 2006, Genesis of ultramafic lamprophyres and carbonatites at Aillik Bay, Labrador: a consequence of incipient lithospheric thinning beneath the North Atlantic Craton: Journal of Petrology, 47(7), 1261-1315.

Tilton, G.R., Bryce, J.G., Mateen, A., 1998, Pb-SrNd isotope data from 30 and $300 \mathrm{Ma}$ collision zone carbonatites in northwest Pakistan: Journal of Petrology, 39, 1855-1874.

Torquato, J.R., Amaral, G., 1974, Algumas idades $\mathrm{K} / \mathrm{Ar}$ do magmatismo mesozóico de Angola e sua correlação com o correspondente do sul do Brasil: Boletim do Instituto de Investigação Científica de Angola, 10, 31-38.
Torró, L., Villanova, C., Castillo, M., Campeny, M., Gonçalves, A.O., Melgarejo, J.C., 2012, Niobium and rare earth minerals from the Virulundo carbonatite, Namibe, Angola: Mineralogical Magazine, 76, 393-409.

Wallace, M.E., Green, D.H., 1988, An experimental determination of primary carbonatite magma composition: Nature, 335, 343-346.

Widom, E., Hoernle, K.A., Shirey, S.B., Schminke, H.U., 1999, Os isotope systematics in the Canary Islands and Madeira: Lithospheric contamination and mantle plume signatures: Journal of Petrology, 40 (2), 279-296.

Woolley, A.R., Church, A.A., 2005, Extrusive carbonatites: as brief review: Lithos, 85, $1-14$.

Woolley, A.R., Kjarsgaard, B.A., 2008, Carbonatites of the world: map and database: Mineralogical Magazine, 71, 718.

Wyllie, P.J., Jones, A.P., Dent, J., 1996, Rare earth elements in carbonate-rich melts from mantle to crust, in Jones, A.P., Wall, F., Williams, G.T. (eds.), Rare earth minerals: Chemistry, origin and ore deposits: London, Chapman \& Hall, 77-102. 